\title{
Ketahanan Pangan Rumah Tangga Anak Stunting Usia 6-23 Bulan di Wilangan, Kabupaten Nganjuk
}

\section{Household Food Security of Stunted Children Aged 6-23 Months in Wilangan, Nganjuk District}

\author{
Dessy Nur Fadzila*, Edy Purwanto Tertiyus ${ }^{1}$
}

\begin{abstract}
ABSTRAK
Latar Belakang: Anak yang berusia dibawah dua tahun rentan mengalami masalah gizi. Masalah gizi dapat disebabkan oleh asupan gizi yang dipengaruhi ketahanan pangan. Rumah tangga yang mengalami rawan pangan dapat disebabkan oleh ketersediaan pangan yang kurang sehingga menyebabkan kurangnya asupan gizi.

Tujuan: Menganalisis kondisi ketahanan pangan rumah tangga dengan stunting dan non-stunting pada anak usia 6-23 bulan di Kecamatan Wilangan, Kabupaten Nganjuk.

Metode: Jenis penelitian yaitu observasional dan menggunakan desain penelitian kasus kontrol. Subjek dari penelitian ini adalah anak berusia 6-23 bulan di Wilangan Kabupaten Nganjuk sebanyak 72 baduta yang didapatkan dari metode simple random sampling. Sampel kelompok kasus sebanyak 36 baduta dan kelompok kontrol sebanyak 36 baduta. Kuesioner United Stated-Household Food Security Survey Module (US-HFSSM) digunakan untuk mengukur ketahanan pangan rumah tangga, dan pengukuran antropometri panjang badan. Uji statistik menggunakan spearman dan chi-square.

Hasil: Sebagian besar baduta non-stunting berada pada rumah tangga yang tahan pangan $(75,0 \%)$. Baduta stunting yang berada pada rumah tangga yang rawan pangan lebih tinggi daripada baduta non-stunting (41,7\%). Penelitian ini menunjukkan hasil tidak terdapat korelasi yang signifikan antara karakteristik keluarga dengan stunting, namun terdapat korelasi antara usia baduta $(p=0,02)$ dan ketahanan pangan rumah tangga $(p=0,041)$ dengan stunting.

Kesimpulan: Rumah tangga yang mengalami rawan pangan berisiko stunting lebih tinggi daripada rumah tangga yang tahan pangan.
\end{abstract}

Kata kunci: ketahanan pangan, stunting, anak usia 6-23 bulan

\section{ABSTRACT}

Background: Children under two years are susceptible to nutritional problems. Nutritional problems can be caused directly by nutritional intake and infection. Nutritional intake can be affected by conditions of household food security. Household food insecurity can be caused by insufficient food availability which causes a lack of nutritional intake.

Objectives: To analyze the condition of household food security with stunted and non-stunted children aged 6-23 months in Wilangan, Nganjuk District.

Methods: This study was an observational and used case-control design. The subjects of this study were 72 children aged 623 months in Wilangan, Nganjuk District obtained from the simple random sampling method. The samples of case group were 36 children and control group were 36 children. The United Stated Household Food Security Survey Module (USHFSSM) questionnaire was used to measure household food security, and anthropometric measurements of body length. The data analysis used by spearman and chi-squared statistical test.

Results: Majority of non-stunted children was in household food security (75.0\%). The stunted children in household food insecurity were higher than non-stunted children (41.7\%). This study showed there was no significant correlation between family characteristics with stunted. But, there was a correlation between the age of children under two years old $(p=0.02)$ and household food security status ( $p=0.041$ ) with stunted.

Conclusions: Household with food insecurity has a higher risk stunted than household with food security.

Keywords: food security, stunted, child aged 6-23 months

*Koresponden:

dfadzila16@gmail.com

${ }^{1}$ Dinas Pertanian dan Ketahanan Pangan, Provinsi Jawa Timur

Jl. Ahmad Yani No.152, Gayungan, 60235, Surabaya, Jawa Timur, Indonesia 


\section{PENDAHULUAN}

Anak yang berusia dibawah lima tahun rentan mengalami masalah gizi, maka dilakukan upaya penanggulangan balita pada 1000 Hari Pertama Kehidupan (HPK) yaitu saat ibu hamil dan saat anak berusia 23 bulan atau dibawah dua tahun (baduta) karena pada masa itu paling efektif dilakukan intervensi ${ }^{1}$. Masalah gizi dapat berdampak pada masa dewasanya ${ }^{2}$. Dampak jangka pendek stunting berupa gangguan kecerdasan otak, perkembangan otak, gangguan metabolisme, serta pertumbuhan fisik, sedangkan dampak jangka panjangnya dapat menurunkan kemampuan kognitif dan prestasi belajar, daya imun menurun, hingga berisiko tinggi mengalami penyakit degeneratif 3 . Terdapat sekitar 155 juta balita di dunia atau sekitar $22,9 \%$ yang mengalami stunting pada tahun $2016^{4}$. Sementara di ASEAN, Indonesia memiliki masalah gizi stunting tertinggi yaitu sebesar $37 \%{ }^{5}$. Data Riskesdas tahun 2013 menunjukkan angka stunting Indonesia mencapai $37,2 \%$ dan prevalensi balita stunting di Jawa Timur mencapai 32,3\%6. Pada tahun 2018 ini, angka stunting Indonesia mengalami penurunan menjadi $30,8 \%{ }^{7}$. Namun dilihat berdasarkan standar WHO angka tersebut masih sangat tinggi karena target penurunan angka stunting adalah kurang dari $20 \% 8$.

Stunting secara langsung dapat disebabkan oleh asupan gizi dan infeksi ${ }^{9}$. Asupan gizi yang tidak adekuat dapat menyebabkan masalah gizi ${ }^{10}$. Penyebab tidak adekuatnya asupan gizi dapat dipengaruhi oleh kondisi ketahanan pangan rumah tangga. Menurut UndangUndang Nomor 7 Tahun 1996 tentang Pangan, ketahanan pangan adalah kondisi terpenuhinya kebutuhan pangan bagi rumah tangga yang tergambarkan dari tersedianya pangan yang cukup, baik jumlah maupun mutunya, aman, merata, dan terjangkau ${ }^{11}$.

Rumah tangga yang mengalami rawan pangan dapat disebabkan ketersediaan serta akses terhadap pangan yang kurang sehingga asupan makanan atau gizi kurang terpenuhi. Jika ketahanan pangan rumah tangga selalu dalam kategori rawan pangan dalam jangka waktu tertentu, maka dapat mengakibatkan kurangnya asupan gizi yang berdampak pada kondisi status gizi ${ }^{12}$. Di Amerika, kerawanan pangan menjadi risiko terganggunya kesehatan, pertumbuhan, dan kognitif $a{ }^{13}{ }^{13}$. Penelitian di Surabaya menunjukkan bahwa keluarga yang mengalami kerawanan pangan sebagian besar memiliki balita stunting ${ }^{14}$ dan rumah tangga yang rawan pangan berisiko 2,7 kali lebih besar memiliki balita stunting ${ }^{15}$.

Kabupaten Nganjuk memiliki angka balita stunting tertinggi sebesar 44,33\% tahun $2013^{16}$. Berdasarkan hal tersebut, penelitian tentang ketahanan pangan pada baduta perlu dilakukan untuk mengetahui faktor yang berperan dalam kejadian stunting. Tujuan dari penelitian ini untuk menganalisis kondisi ketahanan pangan rumah tangga terhadap stunting pada anak usia 6-23 bulan.

\section{METODE}

Penelitian ini merupakan penelitian observasional dengan desain penelitian yaitu casecontrol. Populasi penelitian yaitu semua anak yang berusia 6-23 bulan di Kecamatan Wilangan, Kabupaten Nganjuk yang memiliki z-score panjang badan <-2 SD atau kategori stunting dan $\geq-2$ SD atau kategori normal. Besar sampel penelitian adalah 72 baduta, masingmasing 36 baduta untuk tiap kategori yang dipilih dengan teknik simple random sampling.

Variabel terikat penelitian ini adalah stunting, sedangkan variabel bebas adalah ketahanan pangan rumah tangga dan karakteristik keluarga. Data dikumpulkan dengan cara wawancara menggunakan kuesioner meliputi data karakteristik baduta seperti usia dan jenis kelamin, dan karakteristik keluarga seperti tingkat pendidikan orangtua yang dikategorikan menjadi dua yaitu rendah (maksimal telah menempuh jenjang SMP) dan tinggi (minimal telah menempuh jenjang SMA), pekerjaan ibu, dan pendapatan keluarga berdasarkan Upah Minimum Kerja (UMK) Nganjuk. Kuesioner United Stated-Household Food Security Survey Module (US-HFSSM) digunakan untuk mengukur ketahanan pangan rumah tangga yang terdiri dari 18 pertanyaan untuk yang memiliki balita seputar kondisi rumah tangga dalam 12 bulan terakhir. Setiap pertanyaan kuesioner diberikan nilai 1 . Pengkategorian ketahanan pangan rumah tangga yaitu tahan pangan untuk nilai 0-2, rawan pangan tanpa kelaparan untuk nilai 3-7, rawan pangan dengan kelaparan sedang untuk nilai 8-12, dan rawan pangan dengan kelaparan berat untuk nilai $13-18^{17}$. Baduta stunting dan non-stunting dinilai menggunakan indeks $\mathrm{PB} / \mathrm{U}$ dan dilakukan pengukuran antropometri panjang badan menggunakan alat lenghtboard dengan ketelitian 0,1 cm. Uji spearman digunaan untuk menganalisis korelasi antara ketahanan pangan rumah tangga dan stunting. Sementara untuk menganalisis karakteristik baduta dan orangtua dengan stunting menggunakan uji chi-squared.

Penelitian telah memperoleh persetujuan dari Komisi Etik Penelitian Fakultas Kesehatan MasyarakatUniversitas Airlangga dengan nomor: 458-KEPK. Sementara persetujuan mengikuti penelitian dari baduta diperoleh melalui Inform consent yang ditandatangani oleh ibu atau keluarga baduta.

\section{HASIL DAN PEMBAHASAN}

Pada penelitian ini, gambaran karakteristik baduta meliputi jenis kelamin dan usia baduta, serta karakteristik keluarga meliputi tingkat pendidikan orangtua, pekerjaan, pendapatan dan ketahanan pangan rumah tangga. Tabel 1 menyajikan distribusi karakteristik keluarga baduta dan distribusi karakteristik responden berdasarkan status gizi disajikan pada tabel 2 .

Jenis kelamin baduta sebagian besar adalah lakilaki yaitu $54,2 \%$. Baduta non-stunting mayoritas adalah perempuan sebesar 52,8\%, sedangkan pada baduta stunting mayoritas berjenis kelamin laki-laki $(61,1 \%)$. 
Tabel 1. Distribusi Karakteristik Responden

\begin{tabular}{|c|c|c|}
\hline Karakteristik Keluarga & $\mathbf{n}$ & $\%$ \\
\hline \multicolumn{3}{|l|}{ Jenis Kelamin Baduta } \\
\hline Laki-laki & 39 & 54,2 \\
\hline Perempuan & 33 & 45,8 \\
\hline \multicolumn{3}{|l|}{ Usia Baduta (Bulan) } \\
\hline $6-11$ & 23 & 31,9 \\
\hline $12-23$ & 49 & 68,1 \\
\hline \multicolumn{3}{|l|}{ Pendidikan Ayah } \\
\hline Rendah & 44 & 61,1 \\
\hline Tinggi & 28 & 38,9 \\
\hline \multicolumn{3}{|l|}{ Pendidikan Ibu } \\
\hline Rendah & 36 & 50,0 \\
\hline Tinggi & 36 & 50,0 \\
\hline \multicolumn{3}{|l|}{ Status Pekerjaan Ibu } \\
\hline Bekerja & 8 & 11,1 \\
\hline Tidak Bekerja & 64 & 88,9 \\
\hline \multicolumn{3}{|l|}{ Pendapatan (Sesuai UMK) } \\
\hline$<$ Rp. 1.660 .445 & 52 & 72,2 \\
\hline$\geq$ Rp. 1.660.445 & 20 & 27,8 \\
\hline \multicolumn{3}{|l|}{ Pekerjaan Ayah } \\
\hline Karyawan Pabrik & 3 & 4,2 \\
\hline PNS/POLRI/TNI & 2 & 2,8 \\
\hline Petani & 34 & 47,2 \\
\hline Wiraswasta & 33 & 45,8 \\
\hline \multicolumn{3}{|l|}{$\begin{array}{l}\text { Ketahanan Pangan Rumah } \\
\text { Tangga }\end{array}$} \\
\hline Tahan Pangan & 48 & 66,7 \\
\hline $\begin{array}{l}\text { Rawan Pangan Tanpa } \\
\text { Kelaparan }\end{array}$ & 21 & 29,2 \\
\hline $\begin{array}{l}\text { Rawan Pangan dengan } \\
\text { Kelaparan Sedang }\end{array}$ & 3 & 4,2 \\
\hline $\begin{array}{l}\text { Rawan Pangan dengan } \\
\text { Kelaparan Berat }\end{array}$ & 0 & 0,0 \\
\hline
\end{tabular}

Hasil tersebut sejalan dengan penelitian di Jeneponto, Sulawesi Selatan ${ }^{18}$ dan Semarang, Jawa Tengah bahwa sebagian besar masalah stunting dialami oleh anak laki-laki karena pada anak laki-laki perkembangan motorik kasar lebih cepat sehingga membutuhkan lebih banyak energi ${ }^{19}$. Namun hasil uji dengan Chi-square pada penelitian ini menyatakan bahwa tidak terdapat hubungan antara jenis kelamin dengan status gizi stunting $(p=0,344)$.

Baduta dalam penelitian ini sebagian besar berusia $12-23$ bulan sebesar $68,1 \%$, sedangkan $86,1 \%$ dari usia tersebut merupakan baduta stunting. Uji statistik chi-squared menunjukkan hasil yang signifikan antara usia dan status gizi $(p=0,02)$ dengan nilai $O R$ adalah 6,1 yang dapat diartikan bahwa baduta dengan usia 12-23 bulan berisiko 6,1 lebih besar mengalami stunting dari usia lain. Hasil tersebut sejalan dengan penelitian di Nigeria bahwa sebagian besar baduta stunting adalah pada usia12-23 bulan ${ }^{20}$. Penelitian di Bogor juga menunjukkan bahwa sebesar $73,9 \%$ baduta stunting usianya adalah 12-23 bulan ${ }^{21}$.

Tingkat pendidikan orangtua baduta stunting maupun non-stunting masing-masing memiliki persentase yang sama yaitu $50 \%$ berpendidikan tinggi dan $50 \%$ berpendidikan rendah dengan $p$-value adalah 1 , yang berarti tidak terdapat korelasi yang signifikan antara pendidikan orang tua dengan stunting. Tetapi penelitian di Nigeria menunjukkan bahwa ibu dengan pendidikan rendah akan berisiko empat kali lebih besar mempunyai anak yang stunting daripada ibu dengan pendidikan tinggi ${ }^{20}$.

Sejalan dengan hasil tersebut, penelitian Rahayu di Banjarbaru menunjukkan korelasi stunting dengan tingkat pendidikan ibu, orangtua yang berpendidikan rendah mempunyai risiko 5,1 kali lebih besar mempunyai anak stunting ${ }^{22}$. Penelitian di Bangkalan juga menunjukkan bahwa mayoritas tingkat pendidikan ayah baduta non-stunting adalah pendidikan tinggi $(91,7 \%)^{23}$. Penelitian di Bali, Nusa Tenggara Timur, dan Jawa Barat menunjukkan adanya hubungan antara status gizi dan tingkat pendidikan ayah dengan $(p<0,05)^{24}$. Hal tersebut karena beberapa pekerjaan akan lebih mudah didapatkan apabila berpendidikan tinggi, sehingga dapat meningkatkan pendapatan.

Data karakteristik keluarga menunjukkan bahwa tidak ada perbedaan status pekerjaan ibu antara baduta stunting dan non-stunting, sebagian besar ibu baduta tidak bekerja $(88,9 \%)$. Tingkat pendapatan keluarga baduta stunting dan non-stunting tidak ada perbedaan, keduanya memiliki tingkat pendapatan dibawah UMK sebesar $72,2 \%$. Hal tersebut dikarenakan sebagian besar pekerjaan orangtua baduta baik stunting maupun nonstunting adalah sebagai petani sebesar $47,5 \%$ yang mana pendapatan tergantung pada hasil pertanian dan tidak dapat dipastikan. Apabila hasil panen berhasil, maka semakin tinggi pula pendapatan mereka. Namun apabila hasil panen kurang baik, maka rendah pula tingkat pendapatan. Pada penelitian ini, hasil uji menunjukkan bahwa tidak ada hubungan antara pekerjaan dan pendapatan $(p>0,05)$. Sedangkan penelitian di Bangkalan (2017) menunjukkan adanya hubungan pendapatan dengan stunting ${ }^{25}$, bahwa keluarga yang berpendapatan rendah berisiko lebih tinggi 6 kali mempunyai anak stunting daripada keluarga yang berpendapatan tinggi ${ }^{26}$. Sementara tahun berikutnya yang juga dilakukan penelitian di Bangkalan, menunjukkan bahwa sebagian besar balita non-stunting merupakan keluarga dengan pendapatan diatas UMK $(95,8 \%)^{23}$.

Berdasarkan hasil penelitian, status ketahanan pangan rumah tangga sebagian besar berada pada kategori tahan pangan yaitu sebesar $66,7 \%$ dan tidak ada rumah tangga yang mengalami kerawanan pangan dengan kelaparan berat. Persentase ketahanan pangan rumah tangga baduta disajikan pada grafik 1 . Kerawanan pangan lebih besar terjadi pada kelompok stunting daripada kelompok non-stunting. Pada kelompok stunting, persentase rawan pangan sebesar $41,7 \%$ yang terdiri dari rawan pangan tanpa kelaparan sebesar $36,1 \%$ dan rawan pangan dengan kelaparan sedang sebesar $5,6 \%$. Menurut hasil dari wawancara, keluarga lebih memprioritaskan anak-anak agar kebutuhan pangannya tercukupi, tetapi mayoritas rumah tangga yang rawan pangan tidak jarang merasa khawatir apabila tidak memiliki uang sehingga tidak mendapat cukup makanan untuk keluarga. Hal tersebut dikarenakan sebagian besar pendapatan rumah tangga yang masih dibawah UMK. 
Tabel 2. Distribusi Karakteristik Responden Berdasarkan Status Gizi Baduta

\begin{tabular}{|c|c|c|c|c|c|}
\hline \multirow{3}{*}{ Variabel } & \multicolumn{4}{|c|}{ Status Gizi Baduta } & \multirow{3}{*}{$p$-value } \\
\hline & \multicolumn{2}{|c|}{ Non Stunting } & \multicolumn{2}{|c|}{ Stunting } & \\
\hline & $n$ & $\%$ & $n$ & $\%$ & \\
\hline \multicolumn{6}{|l|}{ Jenis Kelamin Baduta } \\
\hline Laki-laki & 17 & 47,2 & 22 & 61,1 & 0,344 \\
\hline Perempuan & 19 & 52,8 & 14 & 38,9 & \\
\hline \multicolumn{6}{|l|}{ Usia Baduta (bulan) } \\
\hline $6-11$ & 18 & 50,0 & 5 & 13,9 & $0,02 *$ \\
\hline $12-23$ & 18 & 50,0 & 31 & 86,1 & \\
\hline \multicolumn{6}{|l|}{ Tingkat Pendidikan Ayah } \\
\hline Rendah & 22 & 61,1 & 22 & 61,1 & 1 \\
\hline Tinggi & 14 & 38,9 & 14 & 38,9 & \\
\hline \multicolumn{6}{|l|}{ Tingkat Pendidikan Ibu } \\
\hline Rendah & 18 & 50,0 & 18 & 50,0 & 1 \\
\hline Tinggi & 18 & 50,0 & 18 & 50,0 & \\
\hline \multicolumn{6}{|l|}{ Status Pekerjaan Ibu } \\
\hline Bekerja & 4 & 11,1 & 4 & 11,1 & 1 \\
\hline Tidak Bekerja & 32 & 88,9 & 32 & 88,9 & \\
\hline \multicolumn{6}{|l|}{ Pendapatan (Sesuai UMK) } \\
\hline$<$ Rp. 1.660.445 & 26 & 72,2 & 26 & 72,2 & 1 \\
\hline$\geq$ Rp. 1.660 .445 & 10 & 27,8 & 10 & 27,8 & \\
\hline \multicolumn{6}{|l|}{ Pekerjaan Ayah } \\
\hline Karyawan Pabrik & 1 & 2,8 & 2 & 5,6 & \\
\hline PNS/POLRI/TNI & 0 & 0,0 & 2 & 5,6 & 0,488 \\
\hline Petani & 19 & 52,8 & 15 & 41,7 & \\
\hline Wiraswasta & 16 & 44,4 & 17 & 47,2 & \\
\hline
\end{tabular}

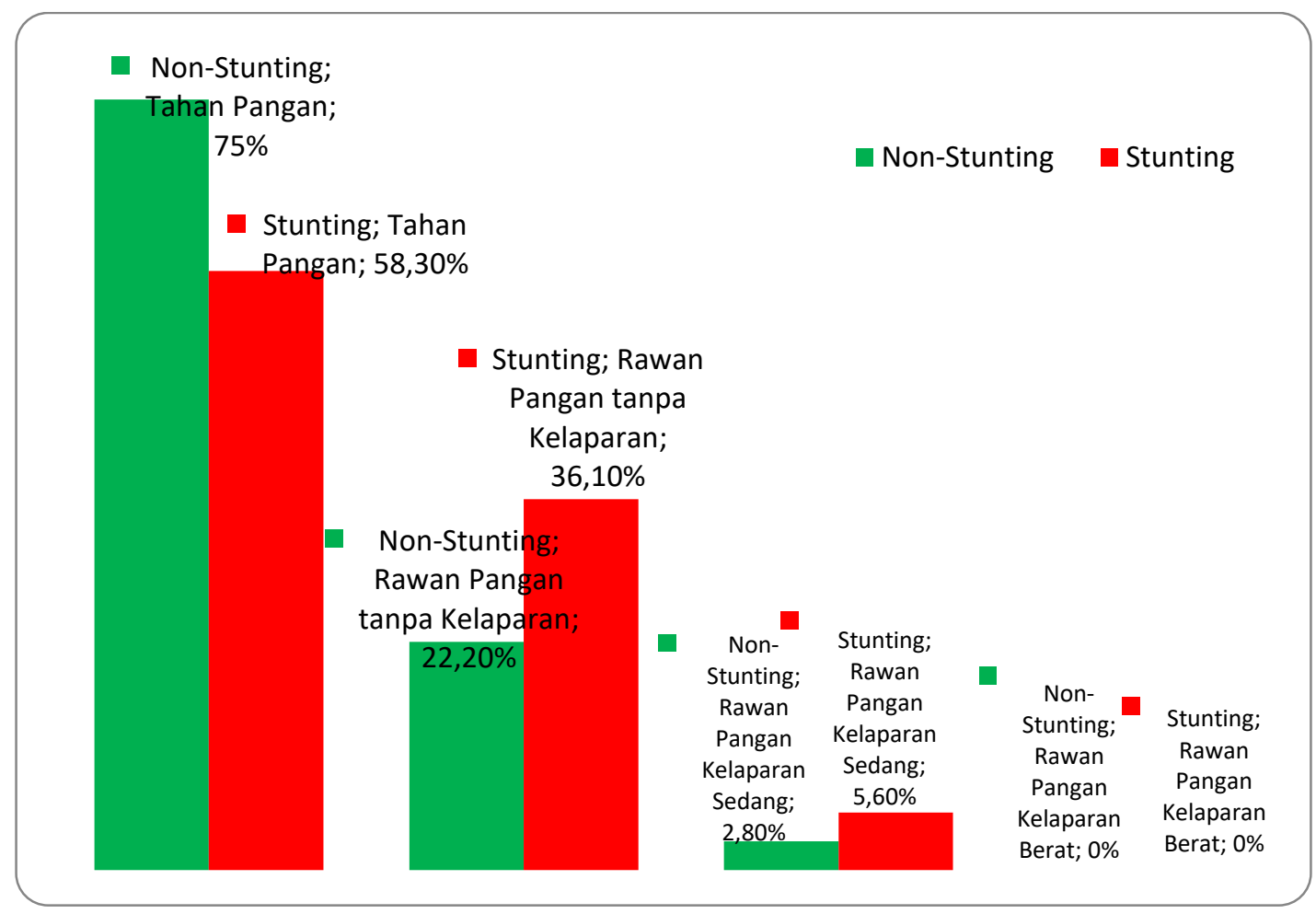

Grafik 1. Persentase Ketahanan Pangan Rumah Tangga Baduta 
Tabel 3. Hubungan Ketahanan Pangan Rumah Tangga dengan Baduta Non-Stunting dan Stunting di Kecamatan Wilangan, Kabupaten Nganjuk

\begin{tabular}{|c|c|c|c|c|c|}
\hline \multirow{3}{*}{ Variabel } & \multicolumn{4}{|c|}{ Status Gizi Baduta } & \multirow{3}{*}{$\mathrm{p}$-value } \\
\hline & \multicolumn{2}{|c|}{ Non Stunting } & \multicolumn{2}{|c|}{ Stunting } & \\
\hline & $\mathbf{n}$ & $\%$ & $\mathbf{n}$ & $\%$ & \\
\hline \multicolumn{6}{|l|}{ Ketahanan Pangan } \\
\hline Tahan Pangan & 27 & 75,0 & 21 & 58,3 & \\
\hline Rawan Pangan Tanpa Kelaparan & 8 & 22,2 & 13 & 36,1 & $0,041^{*}$ \\
\hline Rawan Pangan dengan Kelaparan Sedang & 1 & 2,8 & 2 & 5,6 & \\
\hline Rawan Pangan dengan Kelaparan Berat & 0 & 0,0 & 0 & 0,0 & \\
\hline Total & 36 & 100,0 & 36 & 100,0 & \\
\hline
\end{tabular}

Keterangan: *Signifikan berdasarkan Spearman test correlation

Pada tabel 3, setelah melakukan analisis menggunakan uji spearman, hasil p-value $<0,041$ menunjukkan bahwa terdapat hubungan signifikan dengan arah negatif antara stunting dengan ketahanan pangan rumah tangga. Hasil penelitian ini menunjukkan bahwa semakin baik status gizi baduta yang dilihat dari semakin tinggi nilai $z$-score $\mathrm{PB} / \mathrm{U}$, maka semakin rendah nilai ketahanan pangan yang berarti semakin tahan pangan rumah tangga tersebut. Ketahanan pangan rumah tangga juga berkorelasi dengan stunting di Srilangka ${ }^{27}$, Bangladesh ${ }^{28}$, dan Ethiopia ${ }^{29}$. Menurut hasil wawancara, pada keluarga yang rawan pangan lebih memilih untuk memberikan makanan yang mengenyangkan daripada makanan yang bergizi tinggi karena lebih terjangkau sehingga dapat menghemat pengeluaran. Keluarga kurang memperhatikan kandungan bahan makanan yang diberikan pada baduta sehingga asupan kurang sesuai kebutuhan. Seiring berjalannya waktu, tidak ada perbaikan asupan, sehingga baduta mengalami masalah pertumbuhan.

Hasil penelitian ini sejalan dengan penelitian Jayarni (2018) bahwa status ketahanan pangan rumah tangga berhubungan dengan stunting ( $p$-value = $0,045<\alpha)^{30}$. Sementara di Ethiopia Selatan, rumah tangga yang mengalami kerawanan pangan berisiko 6,7 lebih besar mempunyai anak stunting ${ }^{31}$. Kekurangan dalam penelitian ini adalah tidak melakukan pengambilan data salah satu aspek ketahanan pangan meliputi ketersediaan pangan karena keterbatasan waktu yang tersedia.

\section{KESIMPULAN}

Hasil penelitian menunjukkan bahwa terdapat hubungan usia baduta dan ketahanan pangan rumah tangga dengan stunting, namun tidak terdapat korelasi antara karakteristik keluarga dengan stunting. Peneliti merekomendasikan kepada pihak yang ingin meneliti lebih lanjut untuk mencari beberapa faktor lain yang dapat mempengaruhi stunting seperti riwayat infeksi, hygiene dan sanitasi, ketersediaan pangan, stabilitas, dan pemanfaatan pangan.

\section{ACKNOWLEDGEMENT}

Peneliti mengucapkan terima kasih kepada Badan Kesatuan Bangsa dan Politik Perlindungan Masyarakat Kabupaten Nganjuk dan DInas Kesehatan
Kabupaten Nganjuk yang telah mengizinkan penelitian ini dilakukan, ibu baduta yang telah berpartisipasi guna kelancaran penelitian, serta dosen pembimbing atas arahan, nasihat, dan bimbingan yang telah diberikan.

\section{REFERENS|}

1. Kementerian Kesehatan Republik Indonesia. Situasi Kesehatan Anak Balita di Indonesia. 2015. Available from http://www.depkes.go.id/download.php?file=do wnload/pusdatin/infodatin/infodatin-anakbalita.pdf. Diakses pada 15 Oktober 2018.

2. Dewey, K. G. \& Begum, K. Original Article: Longterm Consequences of Stunting in Early Life. Matern. Child Nutr. 7, 5-18 (2011).

3. Kementerian Kesehatan Republik Indonesia. Situasi Balita Pendek. 2016. Available from http://www.depkes.go.id/resources/download/p usdatin/infodatin/situasi-balita-pendek2016.pdf. Diakses pada 24 Maret 2018.

4. UNICEF, WHO \& World Bank Group. Levels and Trends in Child Malnutrition. 2017. Available from https://data.unicef.org/wpcontent/uploads/2017/05/JME-2017-brochure1.pdf. Diakses pada 5 Februari 2018.

5. UNICEF, WHO \& ASEAN. Regional Report on Nutrition Security in ASEAN. 2, 2016. Available from

https://www.unicef.org/eapro/Regional_Report _on_Nutrition_Security_in_ASEAN_\%28Volume 2\%29.pdf. Diakses pada 6 Februari 2018.

6. Kementerian Kesehatan Republik Indonesia. Riset Kesehatan Dasar 2013. 2013. Availabe from http://www.depkes.go.id/resources/download/g eneral/Hasil Riskesdas 2013.pdf. Diakses pada 5 Februari 2018.

7. Kementerian Kesehatan Republik Indonesia. Hasil Utama Riskesdas 2018. 2018. Availabe from https://www.litbang.kemkes.go.id/wpcontent/uploads/riskesdas/hasil-riskesdas2018.pdf. Diakses pada 22 November 2018.

8. Kementerian Kesehatan Republik Indonesia. Buku Saku Hasil Pemantauan Status Gizi (PSG) Tahun 2017. 2017. Available from http://www.kesmas.kemkes.go.id/assets/upload /dir_519d41d8cd98f00/files/Buku-SakuNasional-PSG-2017_975.pdf. Diakses pada 5 Februari 2018. 
9. WHO. Nutrition Landscape Information System: Country Profile Indicators Interpretation Guide. 2010. Available from http://apps.who.int/iris/bitstream/handle/10665 /44397/9789241599955_eng.pdf?sequence=1. Diakses pada 6 Februari 2018.

10. WHO. Childhood Stunting : Context, Causes and Consequences WHO Conceptual framework. 9, 2013. Available from http://www.who.int/nutrition/events/2013_Chil dhoodStunting_colloquium_140ct_ConceptualFr amework_colour.pdf. Diakses pada 6 Februari 2018.

11. Undang-Undang No . 7 Tahun 1996 tentang Pangan. Undang-Undang No . 7 Tahun 1996 Tentang Pangan. 1996. Available from http://jdih.pom.go.id/showpdf.php?u=5wi43wZ MaMUe9clfuVfMQ26IIDQPaCHTUWrOmU\%2BCr CY\%3D. Diakses pada 17 Mei 2018.

12. Arlius, A., Sudargo, T. \& Subejo. Hubungan Ketahanan Pangan Keluarga dengan Status Gizi Balita (Studi di Desa Palasari dan Puskesmas Kecamatan Legok, Kabupaten Tangerang). J. Ketahanan Nas. 23, 359-375 (2017).

13. Cook, J. T. \& Frank, D. A. Food Security, Proverty, and Human Development in the United States. Ann. N. Y. Acad. Sci. 1136, 193-209 (2008).

14. Safitri, C. A. \& Nindya, T. S. Hubungan Ketahanan Pangan dan Penyakit Diare dengan Stunting pada Balita 13-48 Bulan di Kelurahan Manyar Sabrangan , Surabaya. Amerta Nutr. 1, 52-61 (2017).

15. Masrin, Paratmanitya, Y. \& Aprilia, V. Ketahanan Pangan Rumah Tangga Berhubungan dengan Stunting pada Anak Usia 6-23 Bulan. J. Gizi dan Diet. Indones. 2, 103-115 (2014).

16. Sekretariat Wakil Presiden Republik Indonesia. 100 Kabupaten/Kota Prioritas untuk Intervensi Anak Kerdil (Stunting). 2017. Available from http://www.tnp2k.go.id/images/uploads/downlo ads/Binder_Volume1.pdf. Diakses pada 5 Februari 2018.

17. Bickel, G., Nord, M., Price, C., Hamilton, W. \& Cook, J. Guide to Measuring Household Food Security Revised 2000. 2000. Available from http://hungerfreecommunities.org/wpcontent/uploads/2011/04/USDA-guide-tomeasuring-food-security.pdf. Diakses pada 12 Maret 2018

18. Hafid, F. \& Nasrul. Faktor Risiko Stunting pada Anak Usia 6-23 Bulan di Kabupaten Jeneponto. Indones. J. Hum. Nutr. 3, 42-53 (2016).

19. Setyawati, V. A. V. Kajian Stunting Berdasarkan Umur dan Jenis Kelamin Di Kota Semarang. in The 7th University Research Colloqium 2018 STIKES PKU Muhammadiyah Surakarta 834-838 (2018).
20. Ajao, K. O., Ojofeitimi, E. O., Adebayo, A. A., Fatusi, A. O. \& Afolabi, O. T. Influence of Family Size, Household Food Security Status, and Child Care Practices on the Nutritional Status of Under-five Children in Ile-Ife, Nigeria. Afr. J. Reprod. Health 14, 123-132 (2010).

21. Utami, N. H. \& P., D. S. K. Ketahanan Pangan Rumah Tangga Berhubungan dengan Status Gizi Anak Usia Dibawah Dua Tahun (Baduta) di Kelurahan Kebon Kelapa, Kecamatan Bogor Tengah, Jawa Barat. Gizi Indones. 38, 105-114 (2015).

22. Rahayu, A. \& Khairiyati, L. Risiko Pendidikan Ibu terhadap Kejadan Stunting pada Anak 6-23 Bulan. Penel Gizi Makan 37, 129-136 (2014).

23. Azmy, U. \& Mundiastuti, L. Konsumsi Zat Gizi pada Balita Stunting dan Non- Stunting di Kabupaten Bangkalan. Amerta Nutr. 2, 292-298 (2018).

24. Nadiyah, Briawan, D. \& Martianto, D. Faktor Risiko Stunting pada Anak Usia 0-23 Bulan di Provinsi Bali, Jawa Bawat, dan Nusa Tenggara Timur. J. Gizi dan Pangan 9, 125-132 (2014).

25. Illahi, R. K. Hubungan Pendapatan Keluarga, Berat Lahir, dan Panjang Lahir dengan Kejadian Stunting Balita 24-59 Bulan di Bangkalan. J. Manaj. Kesehat. 3, 1-14 (2017).

26. Mustikaningrum, A. C., Subagio, H. W. \& Margawati, A. Determinan Kejadian Stunting pada Bayi Usia 6 Bulan di Kota Semarang. J. Gizi Indones. 4, 82-88 (2016).

27. Kandeepan, K., Balakumar, S. \& Arasaratnam, V. Nutritional Status and Food Insecurity among the Children in Northern Sri Lanka. Procedia Food Sci. 6, 220-224 (2016).

28. Sarma, $\mathrm{H}$. et al. Factors Influencing the Prevalence of Stunting Among Children Aged Below Five Years in Bangladesh. Food Nutr. Bull. 38, 291-301 (2017).

29. Moges, B., Temam, L., Assefa, B. \& Doyore, F. Household Food Insecurity is the Main Correlate of Childhood Stunting in the Most Critical Period of Growth and Development in Silti Woreda, SNNPR Ethiopia. J. Hum. Nutr. Food Sci. 4, 1-7 (2016).

30. Jayarni, D. E. \& Sumarmi, S. Hubungan Ketahanan Pangan dan Karakteristik Keluarga dengan Status Gizi Balita Usia 2 - 5 Tahun (Studi di Wilayah Kerja Puskesmas Wonokusumo Kota Surabaya). Amerta Nutr. 44-51 (2018). doi:10.20473/amnt.v2.i1.2018.44-51

31. Betebo, B., Ejajo, T., Alemseged, F. \& Massa, D. Household Food Insecurity and Its Association with Nutritional Status of Children 6 - 59 Months of Age in East Badawacho District, South Ethiopia. J. Environ. Public Health 2017, 1-17 (2017). 